\title{
Walls and Holes in Psychosocial Research: From Psychoanalysis to Critique
}

\author{
IAN PARKER
}

University of Leicester and Birkbeck, University of London, UK

This commentary reflects on the different innovative motifs introduced into 'psychosocial' research by the contributions to this special issue; the risk of 'oversubjectification' in research placing undue emphasis on the individual reasoning or feeling subject, the attempt to link the 'feelings' and 'talk' about emotion in one interpretative framework, the place of the interview in research which questions rather than reinforces 'identity', the location of subjects in a 'place-assemblage' rather than in their own selves, and the reconfiguration of 'mindfulness' so that it opens out to social relations rather than evades them. Focussing on the role of psychoanalysis in psychosocial research, I situate these motifs within the analysis of the machinery of 'facialization' offered by Deleuze and Guattari, in which the 'white wall' of signification is complemented and locked in place by the 'black hole' of subjectivity.

Keywords: Psychosocial research, psychoanalysis, discourse, depth, surface, Deleuze and Guattari

\section{Psychoanalytic discourse}

In January this year it was reported that Golders Green crematorium in north London had been broken into on New Year's Day and an urn from 300BC smashed in an apparent attempt to steal it. The ashes spilled on the ground were those of Sigmund Freud. The detective leading investigations described the break-in as 'despicable', and the director of the Freud Museum said they were 'deeply saddened' at the news, 'whatever the motive was' (Kennedy, 2014). You might guess what happened next on the letters page of the liberal-left newspaper the Guardian. One correspondent wrote in to remind readers that Winnicott 'saw that the impulse to steal is connected to the impulse to love, the need to have something felt to be good', and so, the letter went on, 'Since the thief wanted literally to have psychoanalysis, let him be given it. Of all the groups to provoke, has he not managed to select the one most able to offer him understanding and reparation?' (Adès, 2014).

These kinds of events provoke certain kinds of interpretations, and, in the process we see the interpretations accessing and reproducing not only representations of psychoanalysis itself, the discourse of psychoanalysis, but suppositions about what lies beyond discourse as its motivating causes. Those suppositions themselves operate as 'looping effects' in which the categories employed in a discourse come to embed themselves in the subjectivities that employ them (Hacking, 1995). Perhaps the thief could gain redemption by agreeing that their motive was, indeed, connected to the impulse to love. Later that same month the little church of San Pietro della lenca in mountains east of Rome was broken into and a reliquary containing blood of Pope John Paul II was stolen together with a crucifix from a gold and glass circular case kept in a niche of the church. The custodian of the church said that she didn't know what the intention of the thieves had been, but that it felt more like a kidnapping than a theft. She said, 'In a sense, a person has been stolen.' 
We could imagine a wide-ranging and long-standing highly-elaborated theological discourse being put to work around this event, one that would be all-the more complicated if it attempted to link the two thefts. But the conditions of possibility for describing subjectivity and inscribing them in individuals as 'looping effects' so they come to operate within them have shifted significantly in the last hundred years. There is a concern now not so much with the sequestration by evil forces of mortal souls as with the affliction of the ego by the unconscious (Moscovici, 1976/2008). Shortly after these events the new Pope Francis complained about the hero worship during the first year of his papacy, and he insisted, in an interview with Corriere della Sera (one that is itself indicative of a dramatic historical shift) that the pope is a 'normal person', a 'man who laughs, cries, sleeps calmly and has friends like everyone else': 'Depicting the pope as a kind of superman, a kind of star, seems to me offensive'. He then went on to indicate one reason why he was worried, saying that 'Sigmund Freud used to say, if I'm not mistaken, that in every idealisation there is an attack' (Davies, 2014).

It would seem that some kind of psychoanalytic looping effects are at work even on the Holy Father, and Foucault's (1976/1981) suspicion that psychoanalysis has taken the place of the confessional has some truth for the pope, with consequences for how we think about the interpretations we deploy in the clinic or on social texts. This at least draws attention to the fact that psychoanalysis is culturally and historically grounded and should not be wielded as if it were a 'metalanguage', a privileged perspective. Part of the problem we have to grapple with now is precisely that enthusiasts for psychoanalytic discourse too often take it to be universally true in these times of an even more dramatic 'decline of the paternal imago' than that which accompanied the birth of psychoanalysis (Miller, 2005). This is one reason why we should attend to the effects in the clinic of an 'age of interpretation' in which the psychoanalyst risks feeding the unconscious of subjects who want more and more of this kind of discourse (Miller, 1999). Our aim as analysts is to break rather than reinforce the looping effects that operate in this kind of discourse, and our approach to interpretation needs to find a way to do that. To do that, we have to address the dimensions of 'depth' and 'surface' in psychoanalytic research.

\section{Depth and surface}

Studies of psychoanalytic reasoning in Western culture have drawn attention to the way that psychoanalysis works along a 'vertical' axis, part of what we might think of as an 'arboreal' image of psychoanalysis as something that sustains itself by growing up from the roots below the surface to branch up and outwards above our heads. It has been noted, for example, that popular attempts to divine 'causes' of psychological states do not so much now look to the 'positive' and 'flourishing' drivers of behaviour that would be wished for in some government agendas concerned with promoting 'happiness', but actually chime with the more tragic vision of psychoanalysis, but one in which the divided subject is reduced to a normalised account of the individual wallowing in 'narcissistic melancholy' (Bown and Bristow, 2014, pp. 109-110).

Psychoanalysis also operates along a 'horizontal' axis, part of what we might think of as a 'rhizomatic' image of psychoanalysis, as something that maintains itself by insinuating itself into different adjoining domains of discourse and practice, taking root in that way. There have been some interesting analyses of the way that interpretative work is contained within the texts that we presume to be decoding when using psychoanalysis. It has been 
noted, for example, that the online articles of right-wing newspapers do not actually contain much overtly offensive or racist statements, but that the comments boxes then provide the space for the 'meaning' of the text to be elaborated by its readers. This, it is said, is an example of a 'text that reads itself' (Bown and Bristow, 2014, pp. 61-61).

This notion of a 'text that reads itself', a text in which, for example, psychoanalytic notions are put to work and can then proliferate rhizomatically, chimes with arguments made recently in 'Lacanian Discourse Analysis' that a sensitivity to discourse could enable the reader to track the way the text folds around itself to produce certain kinds of reading (Pavón-Cuéllar and Parker, 2013). In place of the use of psychoanalysis as a kind of grid that will trap the text and confirm the assumptions of the analyst, we have an attention to the reflexive moments where the discourse comments upon its own status as a privileged discourse. This is something which may be more intense in psychoanalysis where advocates cannot resist the temptation to spell out the theory as a morally correct account of the world, as if it is a worldview, as if it might function as a metalanguage.

Psychoanalytic ideas are reenergised all the time by other cultural theoretical traditions of work, and this is why Freud saw cultural training as crucial as part of the formation of the psychoanalyst, and different psychoanalytic traditions have recognised this, making efforts to connect with cultural debates. However, we should take care not to see these various frameworks as kinds of gateway drug to the hard stuff, to the real psychoanalysis. This contradictory theoretical material is the real stuff, the stuff of psychoanalysis (as well as of other things). Our work as part of the broad field of psychoanalysis needs to be generous and flexible enough to be able treat the discourse of psychoanalysis as a culturally-specific historically-located form of knowledge whose conditions of possibility have deeper longer roots and broader compass. So, one way of working with psychoanalytic ideas is as components, a number of different components, given the debates between psychoanalytic traditions, of, for example, 'psychosocial' research, and to see psychosocial research as also encompassing debates from feminism, queer politics and postcolonial studies (for example). The other way of addressing psychoanalytic ideas is accept the invitations from those working in other neighbouring traditions to step back from the machinery of psychoanalysis and treat it more critically.

We can go deeper and broader in our self-reflexive critique of psychoanalysis than even an approach that embeds psychoanalysis in a particular regime of truth structured by discipline and confession would do (Foucault 1975/1977, 1976/1981). Foucault's doublecritique is taken even further in the ontological-epistemological challenge posed by Deleuze and Guattari (1980/1987). Guattari was a practising psychoanalyst, including during the time of his writings with Deleuze, and Deleuze himself was invited to be part of Lacan's school, so we should not at all read such critique as hostile to psychoanalysis as such (and Foucault also attended Lacan's public seminars). We can welcome Deleuze and Guattari in alongside psychoanalysis as part of psychosocial research (Brown and Lunt, 2002; Skott-Myhre, 2015).

\section{Psychosocial critique}

What makes psychoanalytic interpretation possible and plausible? There must be two elements to that machine. First, a surface onto which meaning is projected and then picked up in a 'reading', a reading that warrants itself as significant by differentiating between the 'manifest' content, that which is available to all readers, from the 'latent' content which is discovered by those with a particular training and expertise. This is the kind of problem that 
Stephanie Taylor takes seriously and names as 'oversubjectification' in her analysis, and she thus neatly sidesteps one trap in psychoanalytic research. This surface is ostensibly blank, but functions as the screen which is always already written upon, spattered with meanings that the researcher will unpeel from it and pretend to be, at the same time, extracting something deeper from just underneath it. The second element is the subject who has struggled to put meaning on the surfaces around them and then to read them off again, a subject with a degree of interiority within which they might 'reflect' not only what they see but also reflect inside themselves what has been offered to them and rework those meanings in their own 'interpretations'. Jean McAvoy tackles this move in her interesting attempt to hold together an account of 'feelings' and 'talk' in a fully discursive psychosocial account of emotions.

This reflexive subject which operates as a necessary complement to the surface of signification is made present as the origin of the meanings projected onto the wall and made present as the reader, and researcher, who is able to discover them again. The surface is what Deleuze and Guattari call the 'white wall', and the subject the 'black hole'; together they operate as an 'abstract machine', the 'black hole / white wall system' (Deleuze and Guattari, 1980-1987, p. 168). Andrés Di Masso and John Dixon gesture toward a Deleuzian account in their use of the notion of 'place-assemblage', and this gives an opening to critique of psychoanalysis in research. On the one side is the white space of signification, and on the other the black hole of subjectivity, and holding them together is what Deleuze and Guattari (1980/1987, p. 168) call 'an abstract machine of faciality', the apparatus of the 'face' which is not, they insist, universal. Rather, signification and subjectification are produced in a certain way in a particular cultural-historical process:

A single substance of expression is produced. The white wall / black hole system is constructed, or rather the abstract machine is triggered that must allow and ensure the almightiness of the signifier as well as the autonomy of the subject. You will be pinned to the white wall and stuffed in the black hole. This machine is called the faciality machine because it is the social production of face, because it performs the facialization of the entire body and all its surroundings and objects, and the landscapification of all worlds and milieus (Deleuze and Guattari, 1980/1987, p. 181).

For example, in psychoanalytic practice the analyst is typically, stereotypically cast as a 'blank screen' onto whom is projected signifiers from the analysand's past, signifiers which recreate the image of figures in a process we call 'transference' (Parker, 2010). The production of signifiers on the white wall of the analyst requires, for the activity to be psychoanalytically meaningful, that there be a subject with interiority who will then respond to interpretations given by the analyst or produced by themselves, it requires that there also be a black hole of subjectivity. The two elements of the psychoanalytic apparatus are held in place by an abstract machine of faciality in which the analyst withholds expression, or conceals the faces of both partners by use of the couch (Mangabeira, 1999). There is an alternative way of thinking about this which mobilises notions of 'mindfulness' that render problematic the image of the 'mind' that psychology (and psychoanalysis) trades in, and that is what makes the contribution by Steven Stanley, Meg Barker and Victoria Edwards so relevant to these debates.

In psychosocial research the face-to-face encounter between interviewer and interviewee is often a powerful motif, not only to ground what was said in the 'rapport' 
between the two, but also to enable the researcher to claim privileged access to what was really meant by what was said. That is, a black hole of subjectivity is constituted alongside the white wall of the 'data', and in this way key assumptions in mainstream psychology are reproduced (Brinkmann, 2014). Marc Scully's analysis of 'identity' is based on 'interviews', but he handles his 'data' in a way which allows us to see identity as a construction rather than as a source of the meanings we see emerge. As Deleuze and Guattari (1980/1987, p. 169) point out, the 'four-eye machine' has been central to psychological research: 'The face has been a major concern of American psychology, in particular the relation between the mother and the child through eye-to-eye contact'.

This is not to say that we should now try and escape this machine and abandon psychoanalysis. Rather, it means that our psychosocial research includes psychoanalytic theory as a component part that forces us to think in a certain kind of way, and then we also force ourselves to think about what we are thinking. When we do that we are, once again, in the black hole of subjectivity, but at the same time we disrupt the 'looping effects' that normative discourse replicates, to find a 'line of flight' (Deleuze and Guattari, 1980/1987, p. 204) across the surface of interpretations and paint something new on the white walls of the institutions we inhabit.

\section{References}

Adès, R. (2014) Letter, Guardian, Tuesday 21 January 2014, http://www.theguardian.com/theguardian/2014/jan/21/therapy-for-thief-freud-urn (accessed 28 January 2014).

Bown, A. and Bristow, D. (eds) (2014) Why are Animals Funny? Everyday Analysis Volume 1. Alresford, Hampshire: Zero Books.

Brinkmann, S. (2014) 'Doing without data', Qualitative Inquiry, online prepublication at http://qix.sagepub.com/content/early/2014/04/04/1077800414530254 (accessed 3 June 2014).

Brown, S.D. and Lunt, P. (2002) 'A genealogy of the social identity tradition: Deleuze \& Guattari and social psychology', British Journal of Social Psychology, 41, 1, pp. 1-23.

Davies, L. (2014) 'Pope Francis rejects hero-worship and says he is a normal person', http://www.theguardian.com/world/2014/mar/05/pope-francis-hero-worshipnormal-person-vatican (accessed 6 March 2014).

Deleuze, G. and Guattari, F. (1980/1987) A Thousand Plateaus: Capitalism and Schizophrenia. Minneapolis: University of Minnesota Press.

Foucault, M. (1975/1977) Discipline and Punish, London, Allen Lane.

Foucault, M. (1976/1981) The History of Sexuality, Vol. I: An Introduction. Harmondsworth: Pelican.

Hacking, I. (1995) 'The Looping Effects of Human Kinds', in D. Sperber, D. Premack and A. Premack (eds) Causal Cognition. An Interdisciplinary Approach (pp. 351-383). Oxford: Oxford University Press.

Kennedy, M. (2014) 'Urn containing Sigmund Freud's ashes smashed during theft attempt', http://www.theguardian.com/books/2014/jan/15/urn-sigmund-freud-ashessmashed-theft-attempt (Accessed 28 January 2014).

Mangabeira, W. C. (1999) 'On the textuality of objects in disciplinary practice: The couch in psychoanalysis', Psychoanalytic Studies, 1, (3), pp. 327-354. 
Miller, J.-A. (1999) 'Interpretation in reverse', Psychoanalytical Notebooks of the London Circle, 2, 9-18.

Miller, J.-A. (2005) 'A Critical Reading of Jacques Lacan's Les complexes familiaux', http://www.lacan.com/jamfam.htm (accessed 29 May 2014).

Moscovici, S. (1976/2008) Psychoanalysis: Its Image and Its Public. Cambridge: Polity Press.

Parker, I. (2010) 'The Place of Transference in Psychosocial Research', Journal of Theoretical and Philosophical Psychology, 30, (1), pp. 17-31.

Pavón-Cuéllar, D. and Parker, I. (2013) 'From the White Interior to an Exterior Blackness: A Lacanian Discourse Analysis of Apartheid Narratives', in G. Stevens, N. Duncan and D. Hook (eds) Race, Memory and the Apartheid Archive: Towards a Transformative Psychosocial Praxis (pp. 315-332). London: Palgrave.

Reuters in Rome (2014) 'Pope John Paul II's blood stolen from church in Italy', http://www.theguardian.com/world/2014/jan/27/pope-john-paul-ii-blood-stolenchurch-italy (accessed 27 January 2014).

Skott-Myhre, H. (2015) 'Deleuzian perspectives: Schizoanalysis and the politics of desire', in I. Parker (ed.) Handbook of Critical Psychology. London: Routledge. 